interests of the crop producer. If a change in the system of cropping is necessary, recommendations in keeping with the best practice should be available. If postponement of the time of seeding will bring relief from insect attack, the influence on yields from other causes due to late seeding should be carefully studied, and estimated, and compared with the losses occurring from the damage under normal conditions. Some may think these matters belong to other departments of agricultural investigation, and that the recommendations which are the outeome of biological study should be turned over to other persons for their execution. Such action is not in keeping with the erop producer's estimate of agricultural organization, and he is an important factor in the successful development of any remedial plan. Delay consequent on the shifting of the execution of any method or methods is destructive of the best interests of agriculture and oi the various sciences which make up its multifarious structure.

In concluding, I wish to express confidence in the opportunities offered to economic entomologists for the development of preventive and remedial measures against insect attack, by the timely correlation of a thoroughly matured knowledge of agricultural conditions with an exhaustive life-history and habit study.

The discussion of this address was postponed until the afternoon session.

A paper was presented by Mr. Smith:

\title{
CULTIVATION AND SUSCEPTIBILITY TO INSECT ATTACK
}

Bу Јонn B. Sмiтн, New Brunswick, N. J.

(Abstract.)

It is a common complaint in New Jersey by fruit growers that care best for their orchards, that some of their neighbors that never spray suffer less from the pernicious scale than they; and there is a basis of fact for the complaint. In almost every section of the state there are old orchards, chiefly apple, that bear annual crops of good or fair fruit, practically free from scale, though no spraying work is ever done in the orchards and the trees have been infested for years.

Investigation brought out a few facts that seem to be suggestive. First, as a rule, vigorous, sappy growth is much more generally infested and injured than slow, hardy growth. Second, trees growing in well cultivated orchards, highly fertilized, are much more likely to suffer from seale attack than others. Third, trees that grow slowly, or in sod, without much care, are much the more resistant to scale 
attack. Fourth, trees that become infested while young and growing vigorously, suffer much more than trees that do not become infested until they have reached bearing age. Fifth, trees that have been infested for some years, have been more or less persistently treated so as to keep down the insects, and have then been abandoned, not infrequently clean themselves and become and remain practically free from scale afterward.

Some suggestions derived from these facts are, that possibly trees are being stimulated to rapid growth at the expense of hardiness, and that the nitrogenous fertilizers used to produce quick and large trees actually lessen resistant power to insect attack. It would seem in place to inquire whether there should not be a modification of our practice that would induce a hardier growth and one more resistant to scale attack. Instead of adopting a practice calculated to secure size, try to secure one that would give greater hardiness even at the expense of mere growth. That there is a variation in susceptibility among varieties is universally known; it should not be impossible by selection and proper treatment to secure both quality and resistance. It is unscientific to devote ourselves merely to securing and testing spray mixtures, however necessary these may be for immediate results, if there is a possibility of securing exemption by increasing resistance or by adoption of fertilizing methods more in accord with the real needs of the plants.

A general discussion of the paper followed. Mr. Taylor suggested that the fruit grower might lose more by failure to cultivate his orchard in order to dwarf the trees than he would gain by making them more resistant to scale attack.

Mr. Smith stated that the paper should not be construed as an argument to do away with the cultivation of orchards. It is possible that fertilizers might be used to advantage to produce a short, hardy growth rather than a large amount of new wood. He thought it might be desirable to use lime in the orchard and to reduce the amount of nitrogenous fertilizers.

Mr. Felt stated that he had observed in certain parts of New York the same conditions to which Mr. Smith had referred in his paper. He recalled several orchards where the San José scale is doing little, if any, injury, which is probably due to the condition of the trees.

Mr. Rumsey asked if anyone had noted any difference in susceptibility to attack in Ben Davis apple trees. No data on this point was presented.

Mr. Burgess remarked that in his experience the orchards which 
make a very short growth of wood annually and are thereby enabled to.resist scale attack are usually neglected by the owners and do not yield profitable crops of fruit. The best growers aim to secure a large amount of new, vigorous wood, as this insures better quality of fruit. This practice is particularly true in peach culture.

Mr. J. L. Phillips stated that in Virginia fruit growers are attempting to keep their trees in a vigorous condition and are able to secure profitable crops by spraying to hold the scale in check. The trees which are not being injured by the scale and where no spraying is being done, are neglected ones that are not a source of profit to their owners.

Mr. J. G. Sanders called attention to the fact that healthy, vigorous trees increased the fecundity and growth of infesting scale insects to a remarkable degree; the reverse being true in old, enfeebled trees. He stated that by transferring the cottony maple scale (Pulvinaria innumerabilis) to various vigorous plants he had reared forms that had been previously described as distinct species of that genus. By transferring this species from thickly infested maple trees to vigorous young lindens and sycamores he had secured specimens three times the size of the original females and a corresponding increase in egg production resulted.

President Morgan remarked that the paper under discussion was one that should interest the nurserymen and horticulturists and called on Prof. Craig for remarks. The latter expressed the opinion that the entomologists should go very slow in advocating any method of preventing scale injury along the line of doing less spraying or of practising less cultivation in the orchard. Fruit growers are always on the alert for some easy method of destroying this pest and he feared that statements of this sort from officials would be used by careless and indifferent growers as an argument for doing nothing.

A paper was read by Mr. Washburn:

\section{FURTHER OBSERVATIONS ON THE USE OF HYDRO- CYANIC ACID GAS AGAINST THE FLOUR MOTH}

By F. L. Washburn, st. Anthony Park, Minn.

\section{(Withdrawn for publication elsewhere.)}

The Secretary briefly reviewed a paper received from Mr. A. L. Herrera, Mexico City, Mexico, on "Notes on the Orange Worm" (Trypeta ludens), and exhibited a colored plate which accompanied the paper.

Mr. W. D. Hunter gave a description of the able work that Mr. 


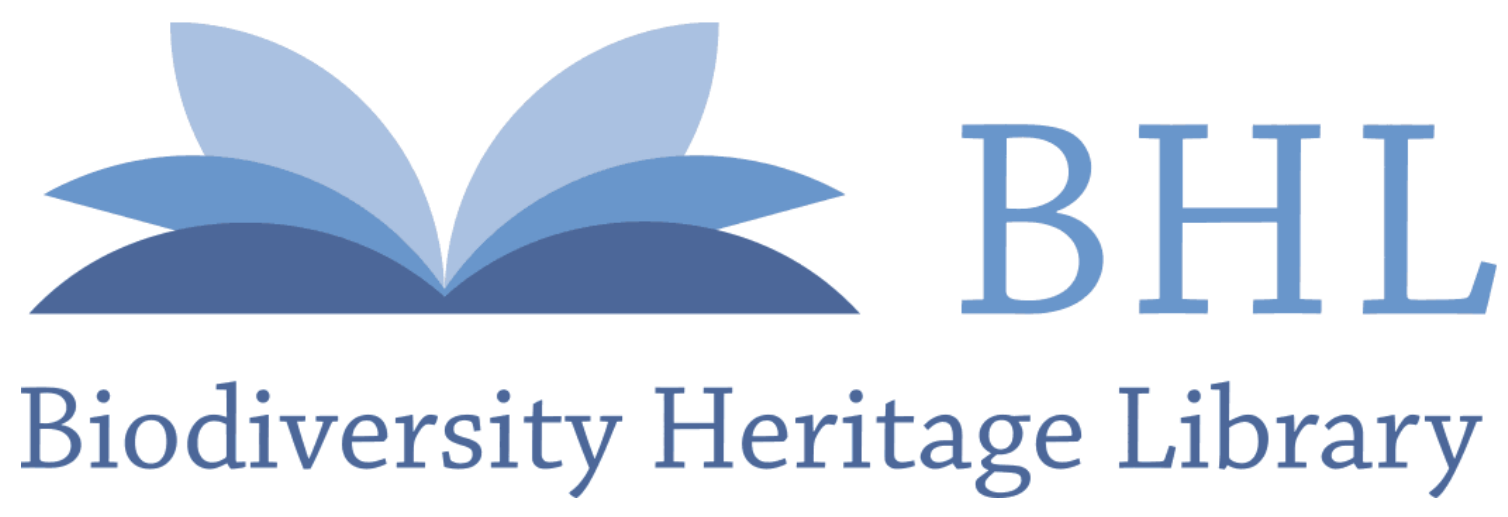

Smith, John Bernhard. 1908. "Cultivation and susceptibility to insect attack." Journal of economic entomology 1(1), 15-17. https://doi.org/10.1093/jee/1.1.15.

View This Item Online: $\underline{\text { https://www.biodiversitylibrary.org/item/37189 }}$

DOI: https://doi.org/10.1093/jee/1.1.15

Permalink: https://www.biodiversitylibrary.org/partpdf/325760

\section{Holding Institution}

New York Botanical Garden, LuEsther T. Mertz Library

\section{Sponsored by}

The LuEsther T Mertz Library, the New York Botanical Garden

\section{Copyright \& Reuse}

Copyright Status: NOT_IN_COPYRIGHT

This document was created from content at the Biodiversity Heritage Library, the world's largest open access digital library for biodiversity literature and archives. Visit BHL at https://www.biodiversitylibrary.org. 